Efficacy of new molecularly targeted drugs in the treatment of renal cell carcinoma (RCC), confirmed in clinical studies in relation to survival and prolongation of time to progression, has became a big chance for patients with metastatic renal cell cancer. Axitinib is a potent and selective receptor tyrosine kinase for vascular endothelial growth factor (VEGFR-1, -2, -3), platelet-derived growth factor $\beta$ (PDGRF- $\beta$ ) and c-KIT.

This is a case report of a 57-year old female patient with a history of left nephrectomy due to clear cell renal cell carcinoma. The patient had received three prior systemic treatments (interferon - sorafenib - everolimus). After consecutive progression the patient was qualified to $4^{\text {th }}$ line therapy - axitinib at a dose of $5 \mathrm{mg}$ twice daily. Partial response to treatment was achieved. After 6 months therapy was stopped due to the disease progression. The total time to progression was 37.5 months. The total surviva time from the disease diagnosis was 45 months.

Based on literature date and own experience we showed that sequential treatment RCC is associated with improved survival. In summary, axitinib may be an effective drug after failure of tyrosine-kinase inhibitor (TKI) therapy in previous lines of therapy.

Key words: renal cell carcinoma, sequential therapy, axitinib, targeted therapies.

Contemp Oncol (Pozn) 2016; 20 (5): 418-420 DOI: $10.5114 /$ wo.2015.51823

\section{Axitinib in sequential therapy in metastatic renal cell carcinoma}

\author{
Agata Kuchar ${ }^{1}$, Beata Hryciuk ${ }^{1}$, Rafał Stec ${ }^{1}$, Michał Mączewski², \\ Cezary Szczylik ${ }^{1}$
}

${ }^{1}$ Military Institute of Medicine, Warsaw, Poland

${ }^{2}$ Centre of Postgraduate Medical Education, Warsaw, Poland

\section{Introduction}

Renal cell carcinoma (RCC) accounts for approximately $3 \%$ of all malignancies. Males predominate among patients $(1.5: 1)$ and peak incidence is between 60 and 70 years of age [1]. At the time of diagnosis disseminated disease is found in 30\% of patients. Lungs, bones, liver and brain are the most common locations of distant metastases of RCC. Disseminated renal cell cancer is considered as incurable disease; average patient survival in the era of targeted therapy is approximately 7.8-43.2 months (depending on the Database Consortium Model risk group) and 5 -year survival rate is $0-13 \%[2,3]$

Recent studies demonstrated that metabolic pathways associated with membrane receptors for growth factors play an important role in RCC etiology and proteins of tyrosine and serine-threonine kinase activity have become a new therapeutic target as well as monoclonal antibodies. Efficacy of new molecularly targeted drugs (sorafenib 2005, sunitinib 2006, temsirolimus 2007, bevacizumab 2009, everolimus 2009, pazopanib 2009, axitinib 2012) in the treatment of RCC, confirmed in clinical studies in relation to survival and prolongation of time to progression, has became a big chance for patients with metastatic renal cell cancer [4-8].

\section{Case report}

This is a case report of a 57-year old female patient with a history of left nephrectomy due to clear cell RCC in December 2008. The patient was in favorable prognostic categories according to Motzer et al. The patient had no family history of malignant neoplasm and no history of chronic diseases. Due to metastatic disease (metastases in lungs), interferon immunotherapy was used as a first line therapy. The best response to treatment was partial regression according to RECIST criteria (version 1.0). After 11 months immunotherapy was stopped due to the disease progression - enlargement of existing lesions. In April 2010 the patient was qualified to $2^{\text {nd }}$ line therapy with a tyrosine kinase inhibitor (sorafenib). The patient received a total of 8 chemotherapy courses. The response to treatment was stable disease according to RECIST criteria. In December 2010, due to the disease progression - appearance of new focal lesions in the liver, the patient was qualified to $3^{\text {rd }}$ line therapy using a selective mTOR inhibitor (everolimus). Marked toxicity was observed during the therapy - anemia grade 3 according to CTC $A E$ that required transfusion of packed red blood cells. The treatment was stopped after 13 courses in January 2012 due to the disease progression - appearance of new lesions in lungs, left adrenal gland and the skeletal system. The patient underwent palliative radiotherapy on the tumor site, $11^{\text {th }}$ rib in January 2012, and then in June 2012 on central nervous system (CNS) area due to focal lesions located in the right parietal and temporal lobes and in the right cerebellar hemisphere. In May 2012 the patient started a $4^{\text {th }}$ line therapy, axitinib at a dose of $5 \mathrm{mg}$ twice daily. Partial response to treatment 


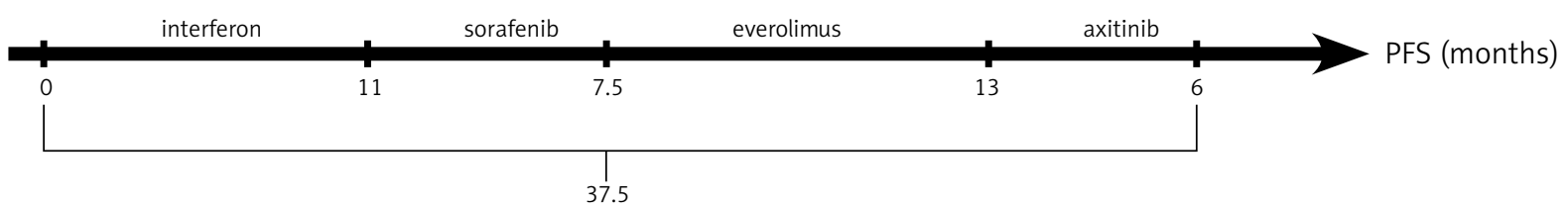

Fig. 1. Progression-free survival (PES)

was achieved. The treatment was stopped in November 2012 due to the disease progression. The total time to progression was 37.5 months (Fig. 1). The patient died in December 2012. The total survival time from the disease diagnosis was 45 months.

The treatment was carried out in accordance with NCCN (National Comprehensive Cancer Network) recommendations and with polish National Health Service.

\section{Discussion}

In January 2012, basing on AXIS study, another drug was approved in the USA for the treatment of an advanced RCC after failure of one line of therapy - axitinib. Axitinib is a potent [50-450-fold more potent that previously used vascular endothelial growth factor receptor (VEGFR) inhibitors] and selective receptor tyrosine kinase for VEGFR-1, $-2,-3$, platelet-derived growth factor $\beta$ (PDGRF- $\beta$ ) and c-KIT [9-11]. Axitinib was shown to potently inhibit VEGFR-dependent proliferation and survival of endothelial cells. In blood vessel of a tumor xenograft, axitinib inhibits phosporylation of VEGFR-2 that is expressed at the target site in vivo and retards tumor growth, results in regression and inhibition of metastases in multiple experimental models of tumors [12]. Table 1 shows summary of clinical trials of axitinib in metastatic renal cell carcinoma.

AXIS was the first phase 3 study of axitinib in the renal cell cancer. This study enrolled 723 patients with an advanced renal cell cancer who progressed during or after a first line therapy. Three hundred and eighty-nine (53.8\%) of these patients previously received sunitinib based therapy, 251 (34.7\%) a cytokine based therapy (interleukin-2 or interferon $\alpha), 59$ (8.2\%) bevacizumab based therapy, 24 (3.3\%) temsirolimus based therapy. The patients were randomized in $1: 1$ ratio to groups receiving axitinib $(n=361)$ or sorafenib $(n=362)$. The primary end point of this study was progression free survival (PFS), while overall survival (OS) was secondary end point. In the whole study population, a statistically significant benefit was found for axitinib versus sorafenib with regard to the primary end point (6.7 vs. 4.7 months, $\mathrm{HR}=0.66 ; p<0.0001$ ). In the subgroup analysis axitinib was more effective than sorafenib in patients receiving cytokines (12.1 vs. 6.5 months; $\mathrm{HR}=0.46 ; p<0.0001)$ and sunitinib (4.8 vs. 3.4 months; $\mathrm{HR}=0.71 ; p=0.01)$ as the first line therapy. No statistically significant differences with regard to PFS between the study groups were found for patients previously treated with bevacizumab or temsirolimus. No statistically significant differences with regard to the secondary end point (OS) were found between the study arms both in the whole population as well as in the subgroups defined by previous therapy. Rate of grade $>3$ toxicity according to CTCAE was similar in both groups. Hand foot syndrome was more common in patients treated with sorafenib (16\% vs. $5 \%$ ), while diarrhea (11\% vs. $7 \%$ ) and hypertension (16\% vs. $11 \%)$ were more common in patients treated with axitinib. The treatment was stopped due to toxicity in $4 \%$ of patients receiving axitinib and in $8 \%$ of patients receiving sorafenib.

A phase 2 study that assessed efficacy and safety of axitinib in 52 patients was published in 2007 [13]. The drug was administered as the $2^{\text {nd }}$ line therapy in patients with advanced renal cell cancer who stopped treatment with interferon $\alpha$, interleukin- 2 or both these drugs due to the disease progression or unacceptable toxicity. Twenty-two patients belonged to the group with favorable prognosis, while 30 to intermediate one. Median time to progression was 15.7 months, and median overall survival time was 29.9 months. Two complete responses to treatment were observed and 21 partial responses, accounting for overall objective response rate of $44.2 \%$ ( $95 \% \mathrm{Cl}: 30.5-58.7)$. An average duration of response was 23 months. Despite the fact that 28 patients experienced grade 3 or 4 toxicity, they were managed and controlled through modifications of the drug dose and supportive therapy.

Another phase 2 study conducted in 2009 proved effectiveness of axitinib therapy in patients with an advanced

Table 1. Summary of clinical trials of axitinib in metastatic renal cell carcinoma

\begin{tabular}{|c|c|c|c|c|c|}
\hline Authors & Phase & Number of patients & Prior therapy & $\begin{array}{c}\text { Median PFS } \\
\text { (months) }\end{array}$ & $\begin{array}{l}\text { Median OS } \\
\text { (months) }\end{array}$ \\
\hline Rixe et al. (2007) & ॥ & 52 & cytokines & $\begin{array}{c}15.7(95 \% \mathrm{Cl}: \\
8.4-23.4)\end{array}$ & $29.9(20.3-N R)$ \\
\hline Rini et al. (2009) & $\|$ & 62 & sorafenib \pm other & $\begin{array}{c}7.4(95 \% \mathrm{Cl}: \\
6.7-11.0)\end{array}$ & $\begin{array}{c}13.6(95 \% \mathrm{Cl}: \\
8.4-18.8)\end{array}$ \\
\hline Rini et al. (2011) & III & 723 & $\begin{array}{l}\text { sunitinib other } \\
\text { cytokines } \pm \\
\text { bevacizumab other } \\
\text { temsirolimus }\end{array}$ & $\begin{array}{c}6.7(95 \% \mathrm{Cl}: \\
6.3-8.6)\end{array}$ & NR \\
\hline
\end{tabular}


renal cell cancer with a history of sorafenib therapy [14]. The study enrolled 62 patients. For $29 \%$ of patients it as a $3^{\text {rd }}$ or higher line of therapy with antiangiogenic drugs, while all patients previously received sorafenib therapy. Partial response to treatment was observed in 14 (23\%) patients, while stable disease in 11 (18\%) patients. An average time to progression was 7.4 months, while an average overall survival time was 13.6 months.

The treatment toxicities were, as in the previous study, controlled and managed through modifications of the drug dose and supportive therapy.

Results of previously conducted studies indicate that sequential use of tyrosine kinase inhibitors (TKI) does not induce cross resistance. On the other hand, it may even overcome resistance to a previously used TKI. Tolerance and toxicity of sequentially used drugs is similar to that encountered for each drug used alone. Furthermore, basing on growing number of retrospective analyses, each line of therapy was shown to have additive effect on PFS and prolong overall PFS [15-26]. Sequential use of the following regimen: TKI - m-TOR inhibitors - TKI could be a good choice in the treatment of $\mathrm{mRCC}$ but larger and appropriate studies are require to provide evidence for standard sequencing treatment [25-28].

In summary, axitinib may be an effective drug after failure of TKI therapy failure in previous lines of therapy, which is supported by this case report and retrospective analyses. This hypothesis requires confirmation in prospective, randomized clinical trials.

The authors declare no conflict of interest.

\section{References}

1. Krzakowski M, Dziadziuszko R, Fijuth J, et al. Zalecenia postępowania diagnostyczno-terapeutycznego w nowotworach złośliwych. Via Medica, Gdańsk 2011.

2. European Association of Urology. Guidelines 2013; 44-45.

3. Szczylik C, Wcisło G. Rak nerki. Współczesna diagnostyka i terapia. Termedia, Poznań 2010; 17-18.

4. Motzer RJ, Hutson TE, Tomczak P, et al. Sunitinib versus interferon alfa in metastatic renal cell carcinoma. N Engl J Med 2007; 356: 115-24.

5. Escudier B, Eisen T, Stadler WM, et al. Sorafenib in advanced clear cell renal cell carcinoma. N Engl J Med 2007; 356: 125-34.

6. Żołnierek J. Leczenie sekwencyjne chorych na rozsianego raka nerki. Wspolczesna Onkol 2009; 3: 113-19.

7. Sternberg CN, Hawkins RE, Wagstaff J, et al. A randomised, double-blind phase III study of pazopanib in patients with advanced and/or metastatic renal cell carcinoma: final overall survival results and safety update. Eur J Cancer 2013; 49: 1287-96.

8. Motzer RJ, Escudier B, Oudard S, et al. Phase 3 trial of everolimus for metastatic renal cell carcinoma: final results and analysis of prognostic factor. Cancer 2010; 116: 4256-65.

9. Food and Drug Administration. www.fda.gov.

10. Rini BI, Escudier B, Tomczak P, et al. Comparative effectiveness of axitinib versus sorafenib in advanced renal cell carcinoma (AXIS): a randomised phase 3 trial. Lancet 2011; 378: 1931-9.

11. Rugo HS, Herbst RS, Liu G, et al. Phase I trial of the oral antiangiogenesis agent AG-013736 in patients with advanced solid tumors: pharmacokinetic and clinical results. J Clin Oncol 2005; 23: 5474-83.

12. Charakterystyka produktu leczniczego: aksytynib.
13. Rixe O, Bukowski RM, Michaelson MD, et al. Axitinib treatment in patients with cytokine-refractory metastatic renal-cell cancer: a phase II study. Lancet Oncol 2007; 8: 975-84.

14. Rini BI, Wilding G, Hudes G, et al. Phase II study of axitinib in sorafenib-refractory metastatic renal cell carcinoma. J Clin Oncol 2009; 27: 4462-8

15. Escudier B, Goupil MG, Massard C, Fizazi K. Sequential therapy in renal cell carcinoma Cancer 2009; 115 (10 Suppl): 2321-6.

16. Sun M, Shariat SF, Trinh QD, et al. An evidence-based guide to the selection of sequential therapies in metastatic renal cell carcinoma. Ther Adv Urol 2013; 5: 121-8.

17. Dudek AZ, Zolnierek J, Dham A, Lindgren BR, Szczylik C. Sequential therapy with sorafenib and sunitinib in renal cell carcinoma. Cancer 2009; 115: 61-7.

18. Sablin MP, Bouaita L, Balleyguier C, et al. Sequential use of sorafenib and sunitinib in renal cancer: retrospective analysis in 90 patients [abstract]. J Clin Oncol 2007; 25 (suppl): 244S. Abstract 5038.

19. Escudier B, Goupil MG, Massard C, Fizazi K. Sequential therapy in renal cell carcinoma. Cancer 2009; 115 (10 Suppl): 2321-6.

20. lacovelli R, Cartenì G, Sternberg CN, et al. Clinical outcomes in patients receiving three lines of targeted therapy for metastatic renal cell carcinoma: Results from a large patient cohort. Eur J Cancer 2013; 49: 2134-42.

21. Blesius A, Beuselinck B, Chevreau C, Ravaud A, Rolland F, Oudard S, Escudier B. Are tyrosine kinase inhibitors still active in patients with metastatic renal cell carcinoma previously treated with a tyrosine kinase inhibitor and everolimus? Experience of 36 patients treated in France in the RECORD-1 Trial. Clin Genitourin Cancer 2013; 11: 128-33.

22. Oudard S, Elaidi RT. Sequential therapy with targeted agents in patients with advanced renal cell carcinoma: optimizing patient benefit. Cancer Treat Rev 2012; 38: 981-7.

23. Afonso FJ, Anido U, Fernández-Calvo O, Vázquez-Estévez S, León L, Lázaro M, Ramos M, Antón-Aparicio L. Comprehensive overview of the efficacy and safety of sorafenib in advanced or metastatic renal cell carcinoma after a first tyrosine kinase inhibitor. Clin Transl Oncol 2013; 15: 425-33.

24. Porta C, Procopio G, Cartenì G, et al. Sequential use of sorafenib and sunitinib in advanced renal-cell carcinoma (RCC): an Italian multicentre retrospective analysis of 189 patient cases. BJU Int 2011; 108 (8 Pt 2): E250-7.

25. http://www.clinicaltrials.gov/ct2/show/NCT00715182?term=tki258\&rank $=8$

26. Global Oncologic Learnings for Dovitinib. www.goldtrials.com.

27. Motzer RJ, Porta C, Vogelzang NJ, et al. Dovitinib versus sorafenib for third-line targeted treatment of patients with metastatic renal cell carcinoma: an open-label, randomised phase 3 trial. Lancet Oncol 2014; 15: 286-96.

28. Albiges L, Choueiri T, Escudier B, et al. A systematic review of sequencing and combinations of systemic therapy in metastatic renal cancer. Eur Urol 2015; 67: 100-10.

\section{Address for correspondence}

\section{Agata Kuchar MD}

Military Institute of Medicine

Szaserów 128

04-141 Warsaw, Poland

e-mail: a kuchar@wp.p

Submitted: 21.09 .2014

Accepted: 23.01.2015 